\title{
AGES OF CHARCOAL SAMPLES OF GEOMORPHOLOGIC INTEREST IN NORTHEAST HUNGARY
}

\author{
EVA CSONGOR, ZOLTÁN BORSY*, and ILONA SZABÓ \\ Institute of Nuclear Research of the Hungarian Academy of Sciences \\ (ATOMKI) Debrecen, Hungary
}

ABSTRACT. There are extended wind-blown sand territories in the northeastern part of the Great Hungarian Plain. Wind-blown sand migration periods were distinpart of the Great Hungarian Plain. Wind-blown sand marcoal samples found in the guished by means of radiocarbon age determination of charcoal samples found in the same type of a thin soil layer of chernozem character in different sand dune exe around The ages of the samples were determined by proportional counter, and are northeast 12,000 years BP. This thin fossil soil layer, which is regionally spread between the blown sand forms evolved in the last glacial period and in the Holocene.

\section{INTRODUCTION}

Wind-blown sand areas form a significant part of the Great Hungarian Plain. These cover nearly 20 percent of the total surface area of the country (fig 1). The largest areas are in the Danube-Tisza Interfluve and in the northeastern part of the Great Plain (Nyirség), then later continued in the Tisza-Bodrog Interfluve.

These blown sand areas were primarily formed on Pleistocene alluvial fans, whose evolutionary stage fostered the start of sand migration in the second half of the Upper Pleistocene. Three main periods of sand migration can be distinguished on the Hungarian wind-blown sand forms but their differentiation was possible only by geomorphologic, stratigraphic, and pedologic considerations (Borsy, 1953; 1961; 1965; 1969; 1978). The exact age of these blown sand forms was not known, however.

Radiocarbon dating in blown sand areas was performed in Hungary only on a single charcoal sample found in a local exposure near the village Madaras in the Danube-Tisza Interfluve (Geyh and others, 1969). No charcoal was disclosed in the sand dune exposures in the northeastern part of the Great Plain up till now. In the recent past, charcoal samples were collected in two different exposures by $\mathrm{Z}$ Borsy near the localities of A) Vajdácska (Tisza-Bodrog Interfluve); B) Nyirmihálydi (Nyirség) (see fig 1 ) and in other exposures (C and D, fig 1 ).

At Vajdácska, charcoal remains from three different fireplaces were exposed at a depth of $3 \mathrm{~m}$, respectively $1 \mathrm{~m}$ inside of a sand dune in a thin layer (ca $0.15 \mathrm{~m}$ ) of fossil soil of chernozem character (fig 2). At Nyirmihálydi, a layer of chernozemic soil, 0.2 to $0.4 \mathrm{~m}$ thick, containing charcoal pieces, separated two different types of blown sand at a depth of $6.5 \mathrm{~m}$ to $4 \mathrm{~m}$ (fig 3 ). It is reasonable to assume that the ages of samples, $i e$, of the soil layers, will be useful chronologic markers between two sand migration periods.

Charcoal samples were cleaned and chemically pretreated to remove carbonate contamination and humic acids.

The counting system was constructed in ATOMKI (Csongor, ms in preparation). The background of the counter was $(4.85 \pm 0.05) \mathrm{cpm}$;

\footnotetext{
* Geographical Institute of the Kossuth University, Debrecen, Hungary
} 
the 95 percent of the NBS oxalic acid activity was $(5.74 \pm 0.06) \mathrm{cpm}$; the activity of the samples was measured for 150 to 200 hours, and was corrected for the barometric pressure variation of the background. The age was calculated with the Libby half-life of 5568 years (table 1). The ages of independent samples from the same site yielded approximately the same value, counted with $1 \sigma$ error.

\section{DISCUSSION}

The measured average age of the charcoal samples found at the village Vajdácska is $12,000 \pm 400$ years $B P$ and at Nyirmihálydi 11,500 \pm 400 years BP. This also means that these chernozemic soils containing the charcoal samples evolved in the Pre-Boreal period. The blown sand underlying the dated soil level had accumulated, undoubtedly, during the last glacial period, and the sand above it was deposited to its present place during the Holocene, in the Boreal period.

This type of fossil soil layer has been found recently in greater sand exposures at a depth of 2 to $10 \mathrm{~m}$ in the NE part of the Great Hungarian Plain at different locations. Consequently, it is of regional spread.

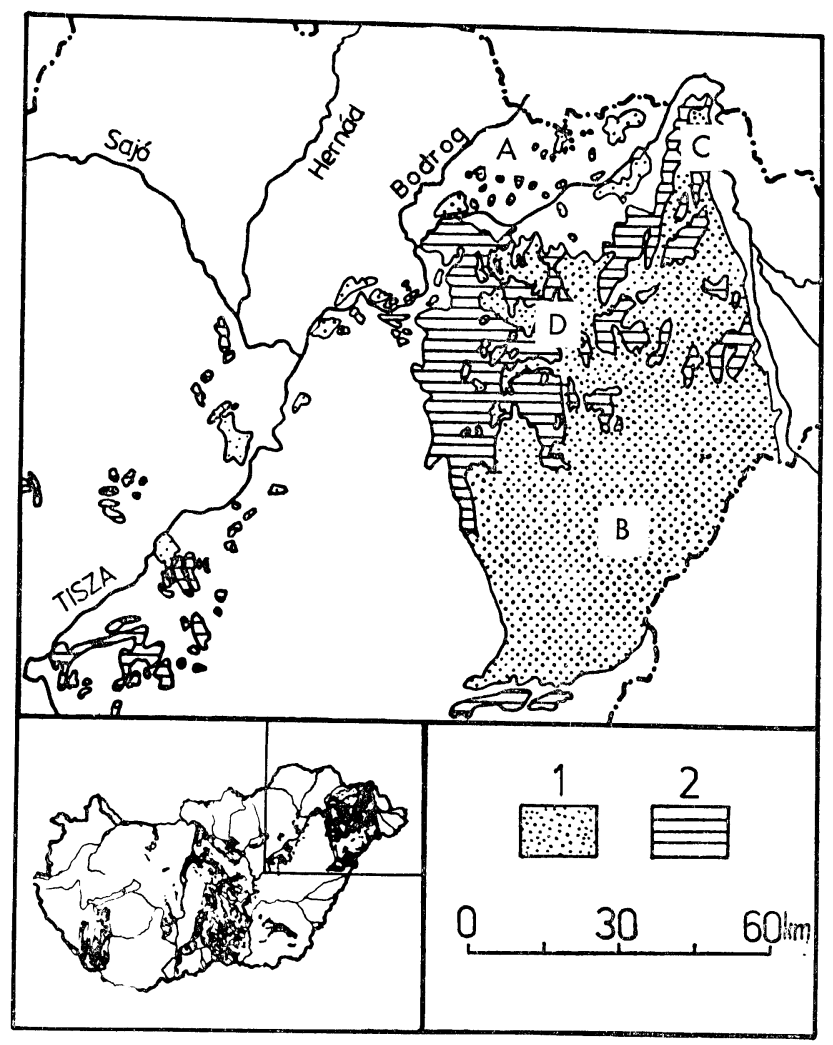

Fig 1. Wind-blown sand areas in northeast Hungary. 1. Wind-blown sand; 2. Blown sand covered with loessy blanket; charcoal sites: A. Vajdácska; B. Nyirmihálydi; C. Aranyosapáti; D. Nyiregyháza. 
These age determinations present exact age markers in the dunes. Thus, fossil soils from different exposures can demonstrate the scale and importance of sand migration in the Pleistocene (last glacial period) and in the Holocene, and provide new data on geomorphology, geology, and paleoclimatology.

These radiocarbon measurements indicate that, on the alluvial fans in Hungary, sand migration was more important in the Boreal period than previously thought.

The presence of such a large quantity of Holocene blown sand also implies a more arid, warmer climate in the Boreal period on the Great Hungarian Plain than at present, or during the New Holocene. In this arid climate, the dunes might have been covered only with straggling steppe-vegetation that could not form a proper cover for sand surfaces, so that a lively sand migration could have occurred in windy periods. This sand movement either destroyed earlier forms or brought about a new form combination that covered the sand forms evolved at the end of the Pleistocene.

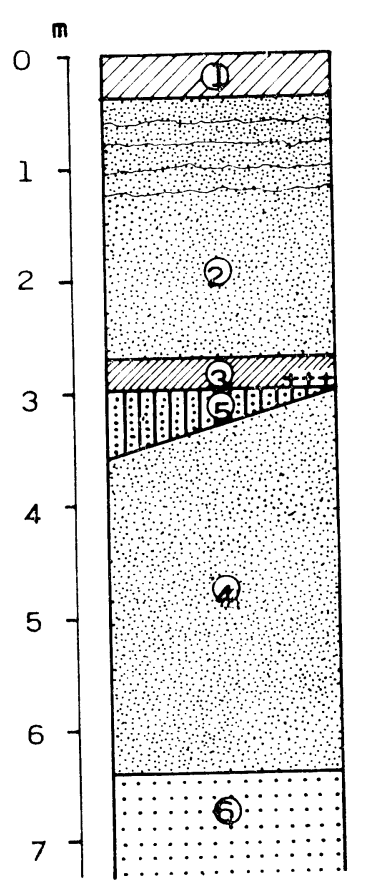

Fig 2.

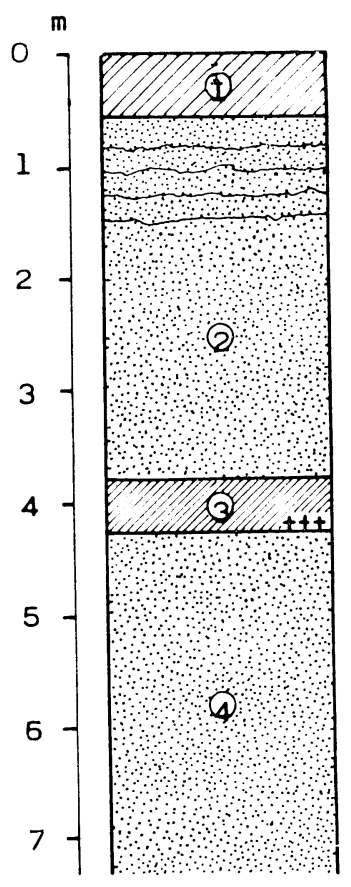

Fig 3.

Fig 2. Exposure of the sand pit south of Vajdácska. 1. Brown forest soil with iron pan layers; 2. Holocene blown sand; 3. Soil layer of chernozem character; 4. Blown sand, formed in the last glacial period; 5 . Loessy sand; 6 . Fluvial sand; +++ Charcoal sites.

Fig 3. Exposure of the sand pit of Nyirmihálydi. 1. Brown forest soil with iron pan layers; 2. Holocene blown sand; 3. Soil layer of chernozem character; 4. Blown sand, formed in the last glacial period; +++ Charcoal sites. 
TABLE 1

Ages of charcoal samples

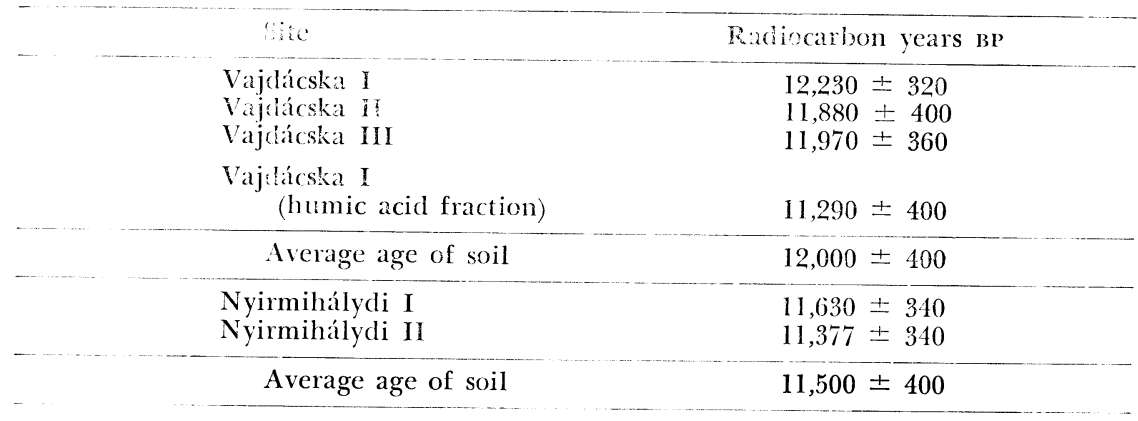

Our conclusions relating to the age of the fossil layer and to the warmer climatic changes in the Holocene agree well with results published by Grootes (1978), who observed the same trend in the climate of northwest Europe for the same period as indicated here.

Precise knowledge of the age of these fossil soils greatly aids further studies of the origins of all the forms of blown sand areas in Hungary, and the clarification of some stratigraphic questions.

\section{REFERENCES}

Borsy, Z, 1953, A Bodrogköz felszinénck kialakulása (The morphogenesis of the Bodrogköz): Földr Ert, p 409-418.

1961, A Nyirség természeti földrajza (The physical geography of the Nyirség): Budapest, Akad Kiadó, p I-227.

1965, The wind-blown sand regions of Hungary: Acta Geol Hungarica, v 9, fasc $1-2$, p 85-94.

1969, Nyirség, in Pécsi, M, cd, A tiszai Alföld: Budapest, Akad Kiadó, p 219-230.

1978, Evolution of relief forms in Hungarian wind-blown sand areas: Debrecen, Kossuth Univ Comm geog Inst, no. 118, p 3-16.

Geyh, M A, Schweitzer, F, Vértes, L, and Vogel, J G, 1969, A magyarországi würmi eljegesedés uj kronológiai adatai (New chronological data on the Würm glacial in Hungary): Földr Ért, p 5-13.

Grootes, P M, 1978, Carbon-14 time scale extended: comparison of chronologies: Science, $v$ 200, p 11-15. 